\title{
Mining-Induced Earthquakes in the Open Pits of the Kola Peninsula
}

\author{
A.A. Kozyrev, V.A. Maltsev, E.V. Kasparian, V.V. Rybin, S.P. Reshetnyak \\ Mining Institute, Kola Science Centre, Russian Academy of Sciences, Russia
}

\begin{abstract}
A geodynamic situation leading to dynamic manifestations of rock pressure in the open pits of the Kola Peninsula is described. Presented in the study are the investigation results of the determination of the state of stress in the rockmasses surrounding the open pits on the Kola Peninsula. Based on the investigations carried out, a conclusion is made that an increase of dynamic manifestations of rock pressure in number and energy in open pits may become a real issue in the near future, and has implications for deep open pit design.
\end{abstract}

\section{INTRODUCTION}

Currently some open pits on the Kola Peninsula are up to $500 \mathrm{~m}$ deep, with their ultimate depth being designed to be 600-800 m. Recovered mineral output in the open pits varies from 19-28 million tonnes per year in the 1980s, to 8-10 million tonnes per year currently, at each of the large open pits. The stripping output has decreased over the last 15 years, being as low as 20-30 million tonnes per year. Taking into account the peculiar mining-engineering and economical features of current mining, the limiting mining depth of, for instance, Zhelezny open pit, Kovdorsky GOK JC may be in future as great as $700-1000 \mathrm{~m}$. There are already some analogous open pits in the world close to that depth.

Most large open pits operated in the Murmansk region (Kola Peninsula) are designed so as to have a substantial factor of safety for the final pitwalls. In a number of open pits, however, some cases are known when individual benches or a group of benches failed.

Failure in open pit walls and benches in hard rockmasses occurs mainly as block sliding along weakened surfaces of natural or artificial joints in the rockmass; as talus within the limits of surface zones, and other similar phenomena characteristic of shallow depth under a low level of stresses occurring in the rockmass (Slope Stability, 2000).

When a final open pit wall of $700-1000 \mathrm{~m}$ is created, the level of vertical stresses occurring in the wall rockmass, whose volumetric weight is about $3 \mathrm{t} / \mathrm{m}^{3}$, may be of about 20-30 $\mathrm{MPa}$ at the pit floor based on the gravitational stress field alone. The horizontal stress value may be $0.3-0.5$ of the vertical stress values, which, in principle, is close, but not enough to the conditions under which the manifestations of rock pressure as dynamic failure are possible (Turchaninov et al., 1978).

Under the gravitation-tectonic stress field, even at a comparatively shallow depth, the level of stress may be significantly higher comparing with that of the gravitational stress field. If stress concentrations occurring near the open pit wall are taken into consideration, the stresses occurring in the rockmass may be compared with the uniaxial compressive strength of rocks, which may result in dynamic rock failure.

\section{DYNAMIC MANIFESTATIONS OF ROCK PRESSURE IN OPEN PITS}

Some cases of dynamic rock failure are documented in open pits where mining was carried out in tectonically-stressed rockmasses. For instance, within the Tsentralny open pit, Apatit JSC, there were dynamic events recorded such as administrative-and-service buildings shaking; plaster crumbling; excavator's dipper jumping on one of the working bench; caving of one of the working open pit benches; sudden caving of orepass walls of the open pit.

The most powerful shocks were recorded on October 26 at 02:35 hours and 08:31 hours (Moscow time). According to the Apatity seismic station data, the 02:35 hours - event was of $\mathrm{E}=10^{6}-10^{7} \mathrm{~J}$; that of $02: 35$ hours was $\mathrm{E}=10^{11}-10^{12} \mathrm{~J}$ $(\mathrm{M}=2.8-4.0)$. So were the 09:06 hours event of $\mathrm{E}=10^{8}-10^{9} \mathrm{~J}$ and the 09:29 hours- event of $E=10^{6}-10^{7} \mathrm{~J}$, which were followed by the events of much lower energy. Seismic shocks of October, 26 were proceeded by foreshocks of October, 25, the most powerful of these occurring at 22:11 hours, $E=10^{7}-10^{8} \mathrm{~J}$, which were followed by a series of aftershocks, those of October, 27, at 04:26 hours, $\mathrm{E}=10^{7}-10^{8} \mathrm{~J}$; at 08:05 hours, $\mathrm{E}=10^{7}-10^{8} \mathrm{~J}$, and those of October, $28, \mathrm{E}=10^{6}-10^{7} \mathrm{~J}$.

In accordance with the data from the high-precision deformation observation station located at the Kirovsky mine (Seismicity in mining, 2002), the direction of deformation changed to the east-west, with a sharp change on October 26, 1995. All the seismic events occurred during the earth tide wave compressive phase. Taking into account the fact that the observation station was at some distance from the focus of the earthquake $(\sim 10 \mathrm{~km})$ and that the precursors were recorded at a distance of 3-5 typical focus sizes, one can postulate a focus size of about $2-3 \mathrm{~km}$, which is consistent with the assessment from the seismological data. As for the 08:31 hours event, it has been recorded by the Karnasurt seismological station in the Lovozersky massif located at the distance of $60 \mathrm{~km}$ north-east from the earthquake focus. According to the seismological data, the earthquake focus was located at a depth of about $1 \mathrm{~km}$, indicating that it was induced by mining operations carried out at the Tsentralny mine. Analysing this case from the retrospective point of view, we consider that it may be interpreted as a mininginduced earthquake.

In addition, during construction and operation of the openings at the Tsentralny mine underground complex 
(orepasses and tunnels), there regularly occur dynamic manifestations of rock pressure in the zone of the open pit influence.

Three seismic events (M 2.8-3.5) were recorded within the Tsentralny mine at 06:35 hours, 06:37 hours, 08:26 hours (the Moscow time) on November 14, 1999 by the Apatity seismic station. The shocks were felt in the orepass 6 area, the Tsentralny mine, in the administrative buildings complex of the Rasvumchorrsky mine, the town of Kirovsk. On October, 11 2003, at about 03:00 hours, in the orepass 6 area, the Tsentralny mine, there was recorded a seismic event of $\mathrm{E}=10^{8} \mathrm{~J}$, resulted in the tunnel concrete support failure. All the seismic events described in the study occurred in the near vicinity of the open pit working zone (the Tsentralny mine) in the zone of stress concentration.

According to the geometrical characteristics of the open pit and to the volume of the rockmass excavated, the Tsentralny mine open pit, Apatit JSC, is compared with the Zhelezny open pit, Kovdorsky GOK JC. For instance, the volumes of the rockmass removed from the open pits of the Zhelezny and Tsentralny mines are approximately equal, being of about 350 million $\mathrm{m}^{3}$. The two open pits are about 350-400 m deep, both being elongated in shape. In terms of geomechanics, the two open pits differ in the level of tectonic stresses occurring in the rockmasses. In the Tsentralny mine the tectonic stress is considered to be high relative to the total state of stress of the rockmass, which is located in a mountainous area. As for the Zhelezny open pit, it is located in flat-lying country. Moreover, the Tsentralny mine rockmass, is influenced by mining-induced stress due to various underground structures (deep orepasses, tunnels) sunk in it, and due to block caving carried out underground by the Rasvumchorrsky mine located in the very vicinity of the Tsentralny mine. Taking all the above factors and observations into account, we consider that dynamic manifestations of rock pressure as intensive scaling and dynamic overbreaks is likely to occur in open pit mining of the Kovdor deposit at depth of about 600-700 m.

\section{STRESS MEASUREMENTS IN OPEN PITS}

Taking into account the importance of final pitwall slope design, the Mining Institute of the KSC, RAS, started investigations in this field in the early 1990s, taking into account the actual stress-strain state and block structure of the hosting rockmass.

Figure 1 shows the station for measurements of parameters of the state of stress of the rockmass by a stress relief method (the Tsentralny open pit, Apatit JSC) as well as the way the stress is distributed within one of the measuring holes. It should be noted that the investigations into the state of stress of the rockmass by the stress relief method were carried out on the open pit benches.

The Table 1 shows the parameters of the stress-strain state of the rockmasses at the the Zhelezny open pit, Kovdorsky GOK JC; Nyorkpakhksky open pit, Vostochny mine; and at Tsentralny open pit, Apatit JSC.

Figure 2 shows a portion of the investigation hole core from one of the measuring stations at the Zhelezny open pit, at horizon $+94 \mathrm{~m}$. The core is taken from the carbonatite formation at depth of 2.25-2.75 m (Melnikov, et al., 2003).

The $\varnothing 58 \mathrm{~mm}$ core is divided into $5-35 \mathrm{~mm}$ thick disks. Some core columns are of a typical convex-concave shape. These dimensions and shape of the core columns are the result of high horizontal stresses occurring in the rockmass normal to the hole axis, i.e., in this particular case, parallel to the open pit contour. Based on the known relations and the uniaxial compressive strength of carbonatites, the absolute values of the stresses occurring in the rockmass are to found to be in the range of $8-25 \mathrm{MPa}$ (Turchaninov et al., 1978). a)

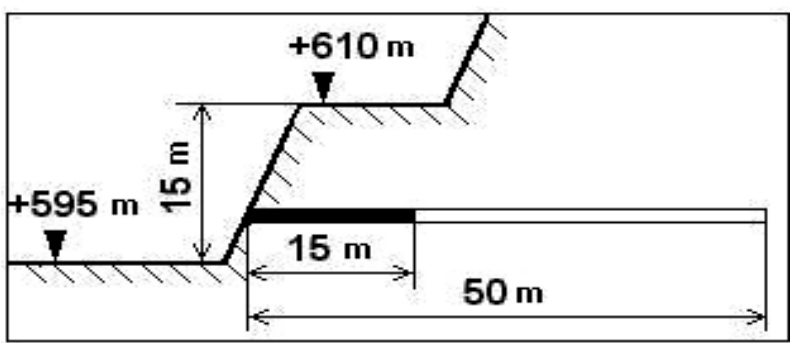

b)

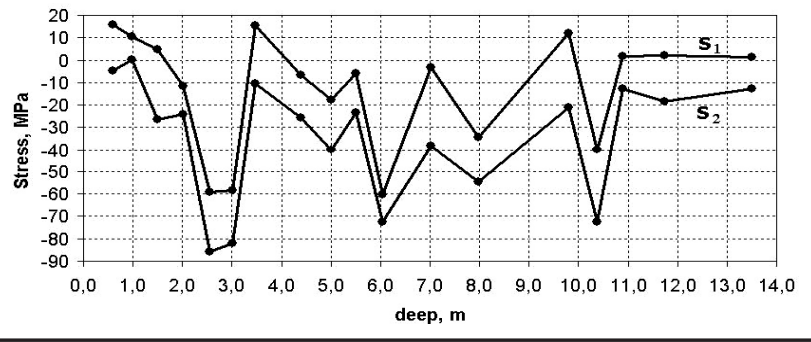

FIG. 1 The design of the station for stress measurements by the stress relief method (a); stress distribution along one of the investigation holes: the lower, middle and upper plots are the maximum, minimum and maximum tangential components of quasi-principal stresses distributed along portion of the hole in which the measurements were made, respectively (b)

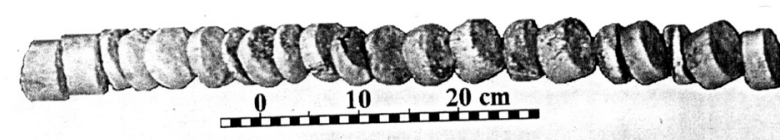

FIG. 2 Core disking in the carbonatite formation. The investigation hole of one of the measuring stations in the Zhelezny mine open pit, hor. $+94 \mathrm{~m}$

Thus, the parameters of the stresses obtained by the stress relief and core disking methods are in some agreement with each other.

Investigations have been carried out at eight measuring stations by the stress relief method. It has been established that in rockmasses enclosing many open pits on the Kola Peninsula, at depths as shallow as $100-150 \mathrm{~m}$ from surface, there occur horizontal stresses parallel to the open pit walls that exceed the lateral rock pressure.

The measuring station at hor. $+610 \mathrm{~m}$, the Tsentralny mine open pit, Apatit JSC, was located in an abnormal zone. The zone was characterized by fine-block fracturing induced by mining, so the data obtained by this station are not typical of the surrounding hard rockmasses. As a whole, on the basis of the investigations carried out in underground openings into the stress-strain state of the rockmass at the Tsentralny mine, one can state that the stress field is of the gravitationand-tectonic type (Turchaninov et al., 1978). As it is seen from the data given in Table, the absolute values of stresses tend to increase with open pit development, and project to levels of 40-50 MPa at depths of 500-600 m below surface. 
TABLE 1 The parameters of the stress-strain state of rocks at the Zhelezny mine open pit, Kovdorsky GOK JC; at the Nyorkpakhksky open pit of Vostochny mine and at the Tsentralny open pit, Apatit JSC

Absolute level of the measuring station, year of measurements
Parameters of stress-strain state of rockmasses

(average values of quasi-principal stresses)

maximum component, $\sigma_{\max }, \mathrm{MPa}$

minimum component, $\sigma_{\min }, \mathrm{MPa}$

Zhelezny open pit, Kovdorsky GOK JC

\begin{tabular}{lcc}
\hline$+94 \mathrm{M}, 2000$ & 20 \\
$+94 \mathrm{M}, 2000$ & 22 & 4 \\
$+142 \mathrm{M}, 2001$ & 8 & -2
\end{tabular}

Nyorkpakhksky open pit, Vostochny mine, Apatit JSC

$\begin{array}{llr}+500 \mathrm{M}, 2002 & 18 & 12 \\ +470 \mathrm{M}, 2003 & 24 & 10\end{array}$

Tsentralny open pit, Apatit JSC

$+610 \mathrm{M}, 2003$

\section{DISCUSSION OF THE STRESS MEASUREMENT RESULTS OBTAINED AT THE OPEN PITS}

The effect of abnormal horizontal stresses occurring in the rockmass is inconclusive. On the one hand, an induced load acts normal to structures oriented perpendicular to the pitwall, which increases friction force along the rock block contacts, and, as a result, the stability of individual benches and the overall wall is improved.

On the other hand, taking into account the predicted level of the stresses occurring at the open pit floor level, as compared with the uniaxial compressive strength of the rockmass, it becomes obvious that the open pit walls can fail in a dynamic manner similar to underground rockbursts. If the open pit is of an elongated shape, the highest stress concentrations and, correspondingly, the highest probability of dynamic failure can be predicted at its shortest side. Dynamic failure will most probably occur as a rupture or a shearing of individual rock blocks along natural discontinuities.

\section{CONCLUSION}

Dynamic failure can become a reality in open pit mining in the nearest future. In deep open pit design, there appears a necessity to take into account not only the initial state of stress in the rockmass hosting the deposit, but the stress redistribution as well. Stress redistribution is due both to large volumes of rock removed from the open pit and to the placement of waste rock dumps, which will result in nonuniform loading of the rockmass and could manifest as mining-induced seismicity.

The possibility of the occurrence of dynamic failure in open pit mining under abnormally high stresses requires the development of mining and sequencing methods as well as specific preventive measures and geomechanical monitoring of the rockmass condition.

In this regard, it is necessary to set up special services responsible for geodynamic safety at the open pit mining operations in excess of 400-500 m depth. These services should be aimed at geomechanical monitoring of the open pit wall rockmass and at timely application of adequate preventive measures.

\section{ACKNOWLEDGMENTS}

This research was supported by Russian Foundation of Basic Research, Grants N 03-05-65258.

\section{REFERENCES}

Melnikov, N.N., Kozyrev, A.A., Reshetnyak, S.P., Kasparian, E.V., Rybin, V.V. (2003) Geomechanical and Technical Substantiation of an Optimal Slope Angle in the Kovdor Open Pit. Proc. of the 7th International Symposium on Mining in the Arctic (edited by John E. Udd \& Gertjan Bekkers). - Iqaluit, Nunavut, Canada, March 30-April 1, 2003. Published by CIM, Montreal, Quebec, pp. 321-327.

Seismicity in mining (2002) Collective of the authors. Apatity, Kola Science Centre RAS. 325 pages (In Russian).

Slope Stability in Surface Mining (2000) Edited by William A. Hustrulid, Michael K. McCarter, Dirk J. A. Van Zyl. - Littleton, Colorado, USA.

Turchaninov, I.A., Markov, G.A., Ivanov, V.I., Kozyrev, A.A. (1978) Tectonic Stresses in the Earth's Crust and Mining Openings Stability - Leningrad, Nauka, 256 pages (In Russian). 